\title{
STUDY ON THE EFFECT OF POLLUTANTS ON THE PRODUCTION OF AAPTAMINES AND THE CYTOTOXICITY OF CRUDE EXTRACT FROM Aaptos suberitoides
}

\section{Studi Pengaruh Polutan terhadap Produksi Aaptamin dan Sitotoksisitas Ekstrak Pekat dari Aaptos suberitoides}

\author{
Ariyanti Suhita Dewi ${ }^{1)^{*}}$, Tri Aryono Hadi²), Hedi Indra Januar ${ }^{11}$, \\ Asri Pratitis ${ }^{1)}$ and Ekowati Chasanah1)

\begin{abstract}
${ }^{1)}$ Research and Development Center for Marine and Fisheries Product Processing and Biotechnology, Ministry of Marine and Fisheries, Petamburan VI, Jakarta, Indonesia 10260 "Corresponding author: ariyanti.dewi@kkp.go.id
\end{abstract} \\ ${ }^{2)}$ Research Center of Oceanography, Indonesian Institute of Sciences, Pasir Putih, Jakarta, Indonesia 14430
}

\section{ABSTRACT}

This experiment was conducted to study the effects of anthropogenic stressor on the spatial variability of secondary metabolites from marine sponge Aaptos suberitoides. Samplings were conducted at 7 sites in Marine National Park of Thousand Islands that are extended within $30 \mathrm{~km}$ off Jakarta bay on late February 2011. Sponges were collected and quantified by means of liquid chromatography coupled with photo-diode array detection, whereas, cytotoxicity of sponges extracts was determined against T47D (breast) cancer cell lines. Results showed that the spatial production of aaptamine and isoaaptamine did not correlate with the quality of their surrounding habitat, despite nitrite and nitrate levels significantly affected the bioactivity of crude extracts.

Keywords: A. suberitoides, aaptamines, spatial production, cytotoxicity, pollutants

\begin{abstract}
ABSTRAK
Penelitian ini dilakukan untuk mempelajari efek tekanan antropogenik terhadap variabilitas spasial metabolit sekunder dari spons laut $A$. suberitoides. Kegiatan sampling dilakukan di tujuh titik yang berada di area Taman Nasional Kepulauan Seribu yang tersebar sepanjang $30 \mathrm{~km}$ dari wilayah Teluk Jakarta pada bulan Februari 2011. Spons dikoleksi dan dikuantifikasi menggunakan kromatografi cair yang dilengkapi deteksi photo-diode array sedangkan sitotoksisitas ekstrak spons diukur terhadap sel kanker T47D (payudara). Hasil penelitian menunjukkan bahwa produksi spasial dari aaptamin dan isoaaptamin tidak berkorelasi dengan kualitas dari habitat disekitarnya, meskipun kadar nitrit dan nitrat mempengaruhi bioaktivitas ekstrak pekat secara signifikan.
\end{abstract}

Keywords: A. suberitoides, aaptamine, produksi spasial, sitotoksisitas, polutan

\section{INTRODUCTION}

Located in the northwest of West Java, Indonesia, the reefs of Thousand Islands have been reported to undergo various levels of pressures from a number of human activities, such as fishing, coral mining, dredging, anchor damage, oil spills, resort construction and the discharge of industrial wastes. Jakarta, with its over 12 millions inhabitants, has contributed to considerable environmental disturbance, due to its domestic effluents (de Voogd \& Cleary, 2006).

For the purpose of assessment on the effects of nutrient enrichment on Thousand Islands' coral reefs, bioindicators are needed to provide an early warning of threats. Sessile taxa are considered suitable as bioindicators for environmental deterioration in marine and freshwaters due to the fact that they exhibit slow mobility and develop high adaptability toward environmental changes (Alcolado, 2007). Sponges as bioindicators for environmental deterioration have been used mainly to monitor heavy metals' build-ups. Others reported their use to observe sedimentation, organic pollutants, inorganic pollutants, and temperature changes (Dewi, 2010).

Sponges have attracted a considerable attention from diverse scientists mostly due to their capability of producing toxic secondary metabolites that are proposed to be utilized as chemical defensive agents such as antipredation, spatial competition, and control of epibiont overgrowth. Since the rate of predation is 
higher in temperate habitats, tropical sponges have evolved more effective secondary metabolites to deter predators (Becerro et al., 2003). Natural spatiotemporal variations of secondary metabolites from marine sponges have been reported in several papers (Page et al., 2005; Abdo et al., 2007), however, only fewer studies observed correlations between fluctuations of isolated bioactive compounds and environmental stressors in their habitats (Thompson et al., 1987; Wiens et al., 2003; Abdo et al., 2007).

Among others, $A$. suberitoides is reported to be one of the most common marine sponges found in Thousand Islands (de Voogd \& Cleary, 2006), which illustrates their constant exposure to pollutants throughout the year. The marine sponge $A$. suberitoides is classified as part of the order Hadromerida and family Suberitidae. They are known to have a unique class of alkaloids as major components namely the aaptamines, which bear a unique $1 \mathrm{H}$-benzo [de] [1,6] naphtyridines structure. Aaptamine (1) and isoaaptamine (2), the major metabolites of $A$. suberitoides, were first reported by Nakamura et al. (1987) and Fedoreev et al. (1989), respectively. Both compounds have been reported to possess anticancer activities against various cell lines i.e. HeLa (Ohizumi et al., 1984), P-388 (Shen et al., 1999), p21 (Aoki et al., 2006), K-562 (Gul et al., 2006); and murin colon (Bowling et al., 2008). Since both metabolites were also found in different genuses, it is suggested that sponge-associated microbes are the true producer of those bioactive compounds (Bowling et al., 2008).

This study aimed to investigate correlations between the presence of anthropogenic stressors with the spatial patterns and cytotoxicity of crude extracts from A. suberitoides in Thousand Islands, Indonesia.

\section{MATERIALAND METHODS}

\section{Sampling Sites}

Samplings were conducted at 8 sites in Marine National Park of Thousand Islands that are extended within $30 \mathrm{~km}$ off Jakarta bay during east monsoon in 2011 (Fig. 1). The sampling locations (from north to south) are as follow: Rengit Island (R) [529' 42.80"

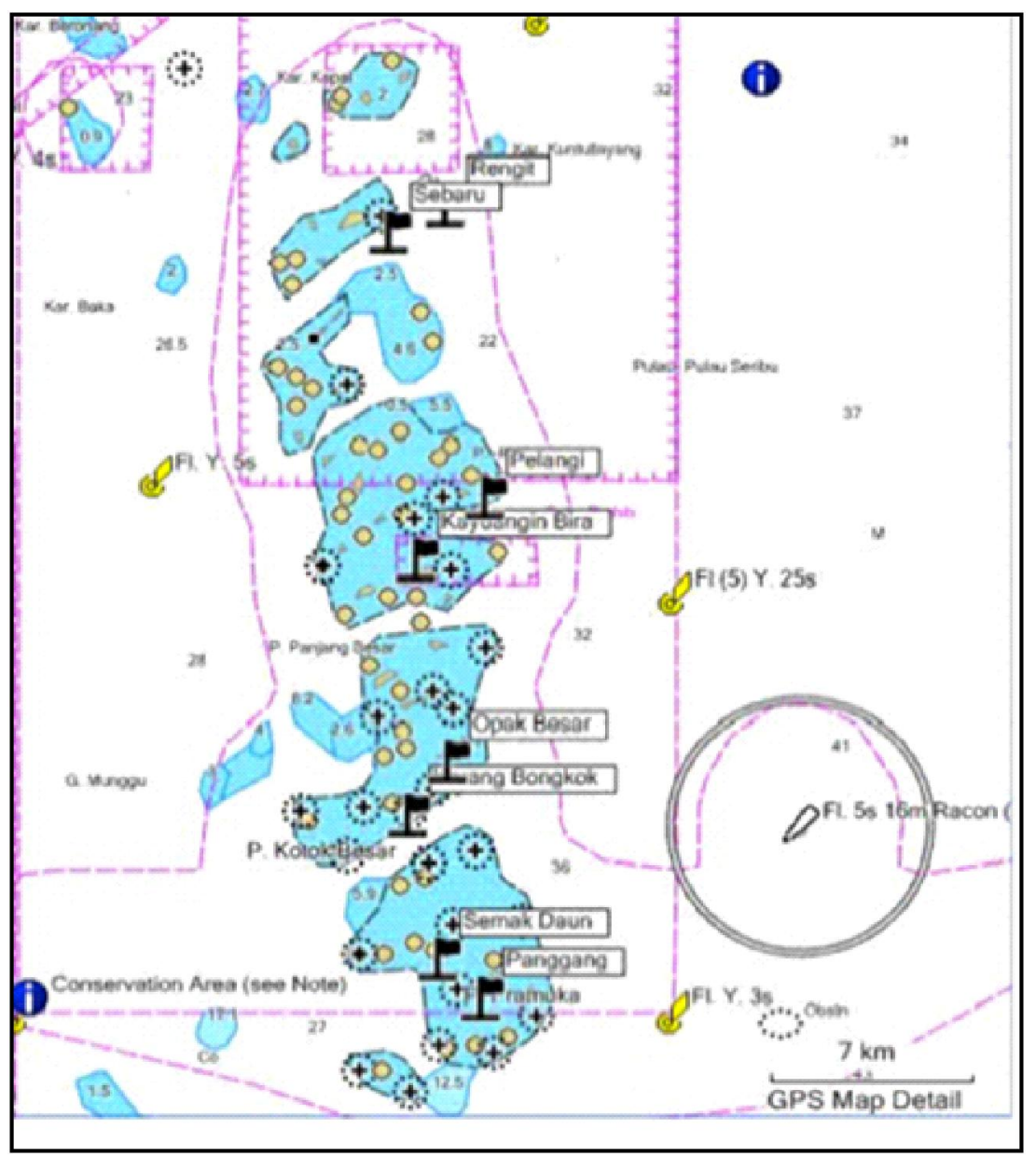

Figure 1. Study sites in Thousand Islands are indicated with flags. 
S, $\left.106^{\circ} 34^{\prime} 44.9^{\prime \prime} E\right]$, Sebaru Besar Island (SB) [5०30' 13.20" S, 106 33' 28.1" E], Pelangi Island [5॰35' 16.9" $\left.S, 106^{\circ} 35^{\prime} 38.50^{\prime \prime} E\right]$, Kayuangin Bira Island (KB) [5 $5^{\circ}$ 36' 27.90" S, 106³4' 5.6" E], Opak Besar Island (OB) [540' 18.60" S, $\left.106^{\circ} 34^{\prime} 4.82^{\prime \prime} \mathrm{E}\right]$, Karangbongkok Island (K) [5०41' 20.58" S, $106^{\circ} 33^{\prime}$ '53.98" E], Semak Daun Island (SD) [5॰44' 4.16" S, 106 34' 35.23" E] and Panggang Island (P) [5॰44' 49.5" S, $106^{\circ} 34^{\prime}$ 5.60" E]. Anthropogenic stressors mainly originate from domestic waste from the southern part of Thousand Islands (Jakarta bay) and oil rig discharge from the northern parts (Java Sea).

\section{Animal Material}

A. suberitoides was not found in Rengit Island. Therefore, sponges were only collected from 7 sites with three replicates for each site. Samples were harvested by hands in each site at a depth of 12-16 $\mathrm{m}$. Collected samples were immediately kept frozen until extraction. Voucher samples are stored in the Research and Development Center for Marine and Fisheries Product Processing and Biotechnology, Ministry of Marine Affairs and Fisheries and the Research Center of Oceanography, Indonesian Institute of Sciences for taxonomic identification.

\section{Analysis of Water Quality}

Water samples were collected at a depth of $5 \mathrm{~m}$. Chemical analysis of water quality (DO, nitrate, nitrite, ammonia, and phosphate) in each location were carried out in situ by using colorimeter Hach DR-890 and reagent kit (Hach, USA) with a series of concentration ranging from $0.001-15 \mathrm{ppm}$ of $\mathrm{O}_{2} ; 0.001-0.5 \mathrm{ppm}$ of $\mathrm{NO}_{3} ; 0.0001-0.35 \mathrm{ppm}$ of $\mathrm{NO}_{2} ; 0.001-0.5 \mathrm{ppm}$ of $\mathrm{NH}_{3}$ and $0.001-2.5 \mathrm{ppm}$ of $\mathrm{PO}_{4}^{3-}$. Methods used were according to Kroger et al. (2009). Dissolved oxygen and acidity were measured by using Hach HQ40d portable meter (Hach, USA). Salinity was measured by using refractometer (Atago, Co. Ltd., Japan).

\section{Chemical Extraction and Quantification}

Approximately $5 \mathrm{~g}$ wet weight of each frozen sample was extracted exhaustively with $10 \mathrm{ml}$ of pure methanol (JT Baker, USA, reagent grade). Approximately $1 \mathrm{ml}$ of each extract was centrifuged to coagulate suspended solid. Each supernatant then concentrated with nitrogen and freeze-dried. After weighing, extracts were re-dissolved in methanol (JT Baker, USA, HPLC grade) to give concentration of 10 $\mathrm{mg} / \mathrm{ml}$. Five micro liters of extract was injected into HPLC system Shimadzu 10-AD with PDA detector and Shimpack VP ODS column $(2.0 \mathrm{~mm} \times 150 \mathrm{~mm})$. Eluent used was $20 \% \mathrm{MeCN} / \mathrm{H}_{2} \mathrm{O}(1 \%$ TFA) at a flow rate of $0.2 \mathrm{ml} / \mathrm{min}$. Concentrations of aaptamine and isoaaptamine were determined by calculating the integral of the peak area and plot it to the standard curve. For the standards, identification was also performed by means of 1D NMR spectra (recorded by Jeol $500 \mathrm{MHz}$ with cryoprobe system) in DMSO-d (Sigma Aldrich, USA) with comparison to that of literature.

\section{Cytotoxicity Assay}

In vitro cytotoxicity assay of aaptamines was performed against T47D breast cancer cell lines according to methylthiazol tetrazolium (MTT) method by Zachary (2003). Reagents used in this assay were purchased from Sigma Aldrich (USA). Breast cancer cell lines were obtained from the Laboratory of Industrial Technology Development and Biomedics, the Agency for the Assessment and Application of Technology, Indonesia (BPPT).

\section{Statistical Analysis}

Spearman's correlation coefficient $\left(r_{s}\right)$ was used to examine correlations between aaptamines concentration and water parameters. Relationships between dependent values of aaptamines and independent variables of water parameters were examined by means of regression analysis. Biophysic patterns of both are presented in contour maps (software Surfer-Golden).

\section{RESULTS AND DISCUSSIONS}

\section{Taxonomic Identification}

A. suberitoides has a massive and blunty lobate form with a smooth and sometimes elevated surface. The color is reddish black with vivid yellow for interior. The consistency is compact and spongy (Fig. 2A). Osculum is around $3-5 \mathrm{~mm}$ in diameter. The skeleton contains many spicules erect with points toward the outside (ectosome) (Fig. 2B). Whereas its spicules consist of strongyloxeas with two different size ranges, the larger ones are $700-1200 \mu \mathrm{m}$ and the small ones are $110-300 \mu \mathrm{m}$ (Fig. 2C). There is a difference with Laubenfels's description (1954) about $A$. suberitoides particularly on the spicules. Our specimen has larger and longer spicules than Laubenfels's. In microscopy observation, the length instead of the width was measured, due to the different habitat of our specimen than that of Laubenfels's.

\section{Analysis of Water Quality}

The result of water quality analysis is shown in a contour map (Fig. 3). Analysis of water quality showed that dissolved oxygen was concentrated only in the 


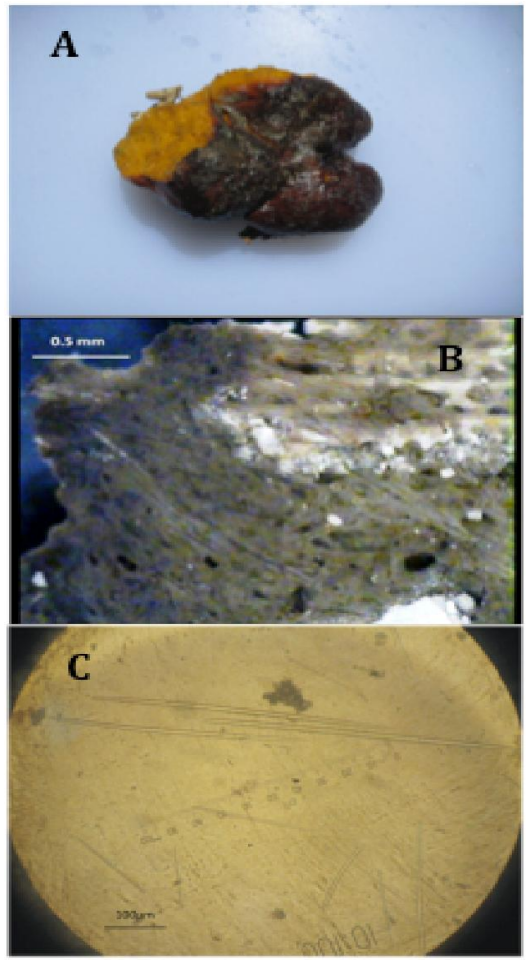

Figure 2. (A) Specimen of $A$. suberitoides; (B) Skeleton profile (100x magnification); (C) Spicule profile (200x magnification).

A

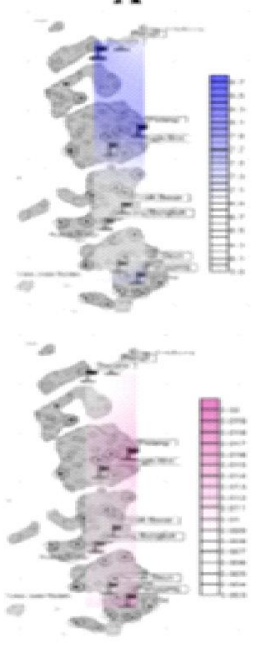

E
B

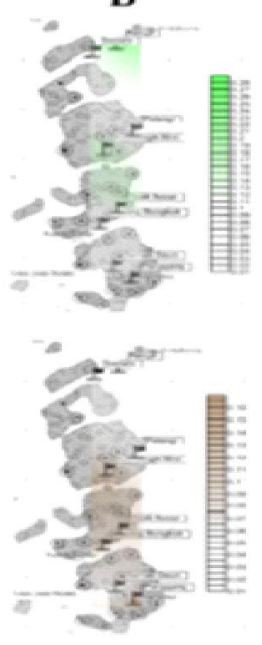

F
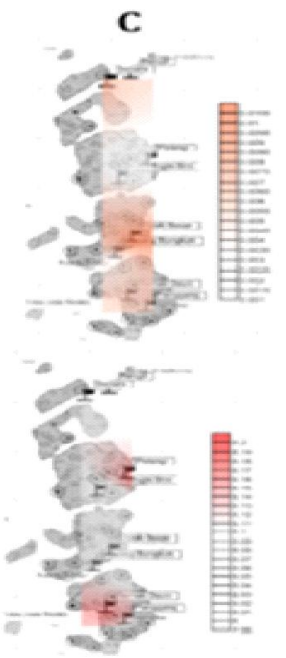

G

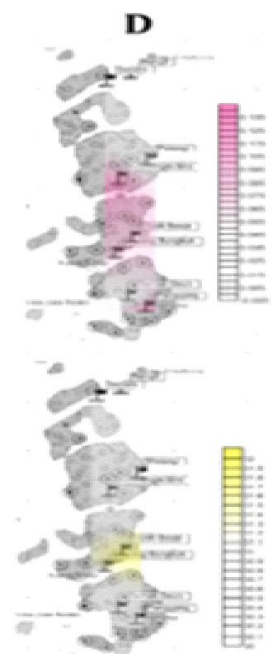

H

Figure 3. Contour maps of water quality parameters in Thousand Islands waters during February 2011: A. Dissolved oxygen (DO); B. Phosphate; C. Nitrite; D. Ammonia; E. Nitrate; F. Total nitrogen; G. Acidity; H. Salinity.

northern part of the marine park. Phosphate contents demonstrated an increasing trend in the northern zone, whilst those of nitrogen were concentrated in the middle and southern zone. Organic build-ups were shown dispersed in the southern zone, whereas seawater acidity was spread out in middle and southern area. Salinity is relatively similar at all locations during sampling.

\section{Chemical extraction and quantification}

Aaptamine and isoaaptamine for standards were isolated and showed UV absorbance at 236; 255; 384 $\mathrm{nm}$ and $249 ; 265 ; 410 \mathrm{~nm}$, respectively. The structure of aaptamine and its isomer is shown in Fig. 4. Identification by means of 1D NMR demonstrated similar data to that of literature (Nakamura et al., 
1982). Average yield of isolated of aaptamine per wet weight appeared at $0.08 \mathrm{mg} / \mathrm{g}$ and that of isoaaptamine appeared at $0.02 \mathrm{mg} / \mathrm{g}$ (Fig. 5). The highest differences were found betweeen concentrations of aaptamine within sites and replicates $(p>0.05)$ (Table 1). On the other hand, concentrations of isoaaptamine exhibited significant differences within replicates and sites $(p<0.05)$ (Table 1). Similarity test betweeen groups showed that aaptamine exhibited variability among replicates but not among sites (Tukey test, $p>0.05$ ) (Table 1). Whereas, isoaaptamine demonstrated variability both within replicates and sites (Tukey test, $p>0.05$ ) (Table 1). The concentrations of both aaptamine and isoaaptamine were found to have no significant correlation with water quality $(p>0.05)$ (Table 2).

\section{Cytotoxicity of Crude Extracts}

The bioactivities of crude extracts were measured based on their cytotoxicity against human breast cancer cell lines (Fig. 6). The highest cytotoxicities were shown by crude extracts from Pelangi and Kayuangin Bira islands by killing approximately $75 \%$ of cancer cells. The lowest cytotoxicity was displayed by crude extract from Sebaru island ( $50 \%$ viable cells).
However, this fluctuation of cytotoxicity was not considered significant $(p>0.05)$ (Table 1). On the other hand, nitrite $\left(p<0.05, r^{2}=-0.75\right)$ and nitrate levels $\left(p<0.05, r^{2}=0.90\right)$ strongly affected the bioactivities of crude extracts (Table 2). No correlation between cytotoxicities and the concentration of aaptamines was found based on the Spearman test (Table 3).

There are two major causes of pollutants in Thousand Islands, i.e. oil rig discharge in northern zone and domestic waste from the Jakarta bay. Although we expectantly observed concentrated pollutants in both zones, however, brought by the east monsoon in October, the sea surface currents disperse pollutants westward, leading to the accumulation of pollutants in middle zone.

Similarly, aaptamine and isoaaptamine showed trend of build ups in the same zone, although no significant difference was found among sites. Correlations between water quality and concentration of both compounds were not found. This is probably due to the fact that the pollution gradient along the sampling site was relatively similar so that no variation of aaptamines was detected.

Interestingly, the presence of inorganic nitrogen in the ecosystem affected cytotoxicity of crude extracts,<smiles></smiles>

(1) $\mathrm{R}=\mathrm{H}, \mathrm{R}_{1}=\mathrm{CH}_{3}$

(2) $\mathrm{R}=\mathrm{CH}_{3}, \mathrm{R}_{1}=\mathrm{H}$

Figure 4. Chemical structure of aaptamine (1) and isoaaptamine (2).

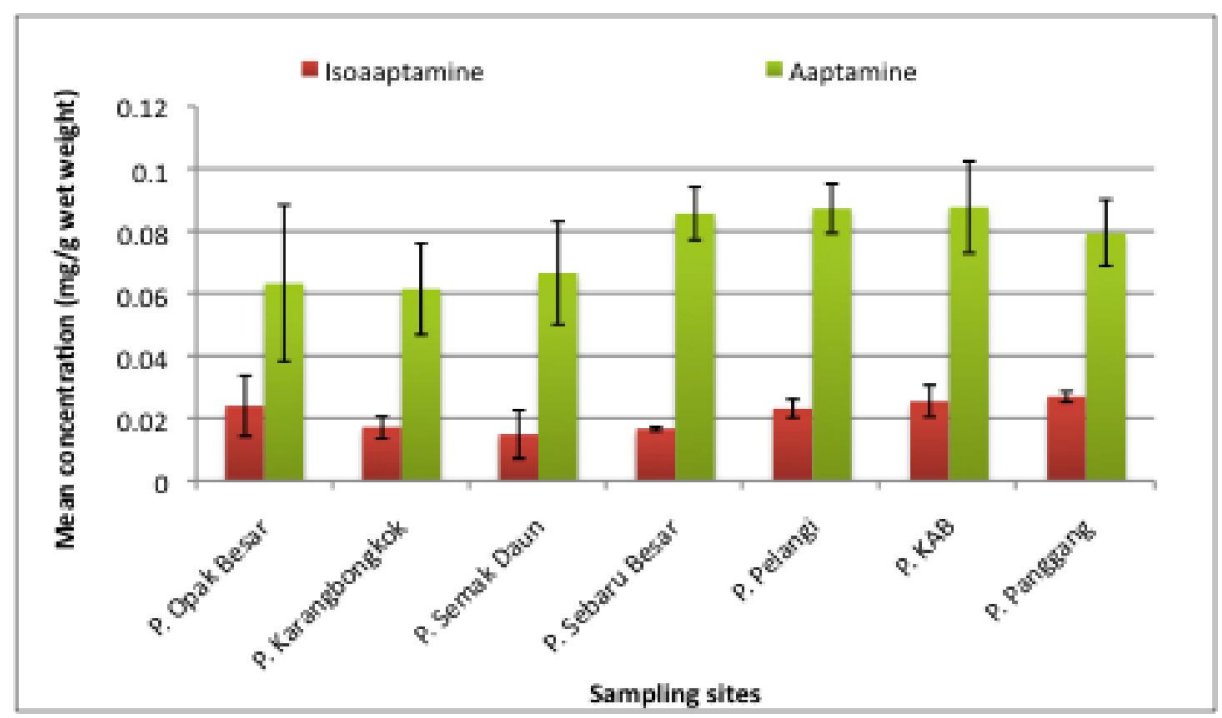

Figure 5. Mean concentration of aaptamines from $A$. suberitoides collected along the sampling sites $(p>0.05, N=21)$. 
suggesting that other secondary metabolites possibly responsible for their activity. Furthermore, the cytotoxicity of crude extracts is probably related to the role of associated bacteria in $A$. suberitoides that is known as the true producer of secondary metabolites. Bacterial symbionts, especially cyanobacteria, in sponges have been reported to play role in nitrogen cycle (Fiore et al., 2010). In this case, bacteria utilize available nitrate in the environment and contribute to nitrogen fixation. Hence, we suggest that inorganic nitrogen level in seawater is probably affecting the activity of sponge-associated

Table 1. Effect of locations and replicates on the concentration of aaptamines and their cytotoxicites against breast cancer cell lines. Bold values indicate significant correlations

\begin{tabular}{lcccccccccc}
\hline $\begin{array}{l}\text { Source of } \\
\text { Variation }\end{array}$ & df & \multicolumn{3}{c}{ Isoaaptamine } & \multicolumn{3}{c}{ Aaptamine } & \multicolumn{3}{c}{ T47D } \\
\cline { 2 - 11 } & & MS & $\mathbf{F}$ & $\mathbf{P}$ & MS & $\mathbf{F}$ & $\mathbf{P}$ & MS & F & P \\
\hline Locations & 6 & 634901.5 & 4.59 & $\mathbf{0 . 0 1}$ & 1565160 & 1.28 & 0.34 & 341.34 & 2.52 & 0.12 \\
Replicates & 2 & 705451.3 & 5.1 & $\mathbf{0 . 0 2}$ & 4487257 & 3.66 & 0.06 & 86.28 & 9.96 & $<\mathbf{0 . 0 1}$ \\
Error & 12 & 138439.8 & & & 1226461 & & & 34.26 & & \\
\hline
\end{tabular}

Table 2. Spearman correlation for the effect of water quality on the concentration of aaptamines and the bioactivity against breast cancer cell lines. Bold values indicate significant correlations.

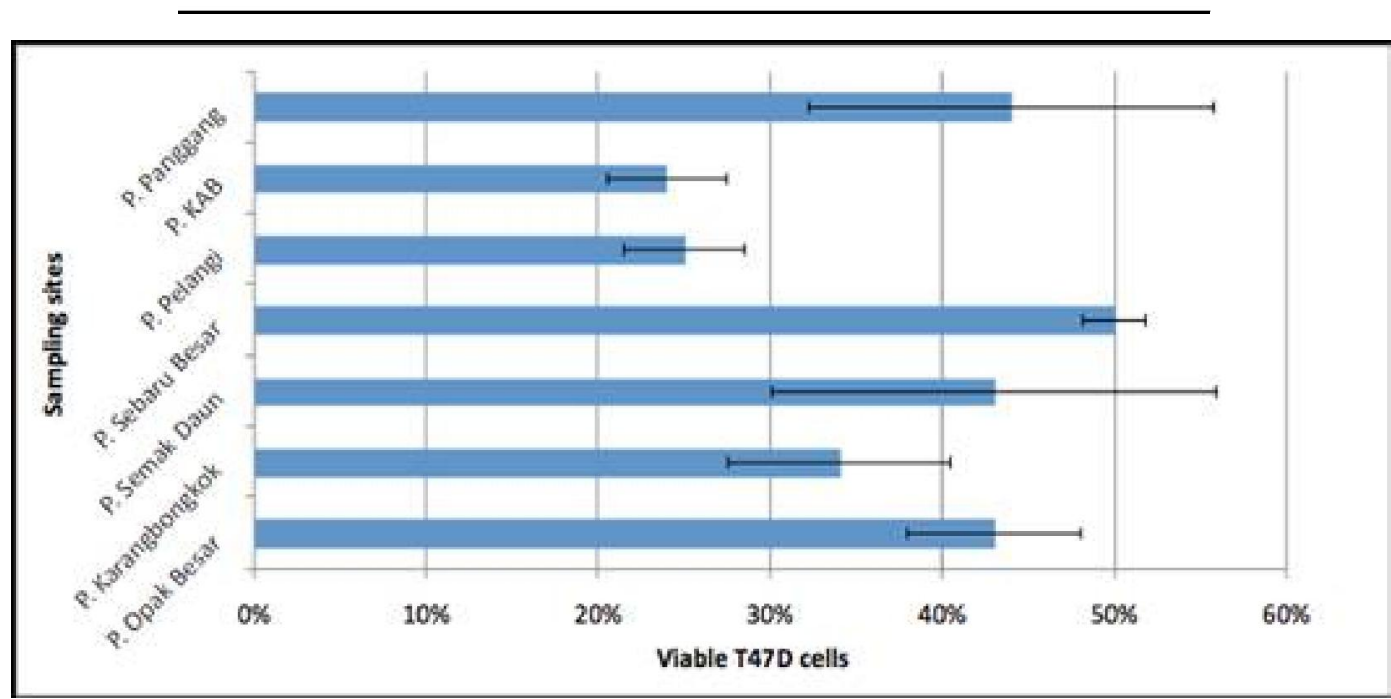

Figure 6. Mean viable cells of T47D after the addition of crude extracts from $A$. suberitoides $(p<0.05, N=21)$

Table 3. Spearman correlations between aaptamines and bioactivities of crude extracts 
cyanobacteria in producing bioactive compounds. However, further research needs to be conducted to test this idea.

In the ocean, pollution of inorganic nitrogen mainly comes from domestic and industrial run off in addition to aquaculture practice that may lead to three major environmental hazards such as acidification and eutrophication, as well as impairment on aquatic animals (Camargo \& Alonso, 2006). Several other sponges have been reported as potential bioindicator for environmental degradation due to municipal wastewater based on their relative abundance, for instance: Amphimedon viridis, Cliona celata, Clionaviridis, Mycale microsigmatosa, Scopalina ruetzleri (Alcolado, 2007) and Cliona delitrix (Carballo et al., 1994).

Various authors have also reported spatial variation of secondary metabolites in sponges due to environmental factors. Thompson et al. (1987) firstly proposed that environmental conditions, instead of genetic differences, affected the composition of diterpene in Rhopaloeides odorabile. Also, variability in salicylihalamide A from Haliclona sp. in different locations was reported to correlate with water temperature (Abdo et al., 2007).

On the other hand, other research reported that spatial variability of bioactive compounds in marine sponge Mycale hentscheli was not directly correlated to water temperature, depth, or salinity (Page et al., 2005). Furthermore, correlation of secondary metabolites production in Acanthella cavernosa (Jumaryatno et al., 2007) as well as Aplysina fulva (Nunez et al., 2008) and their ecological conditions is remained undetermined. According to Cooper (2009), there are five selection criterias for an appropriate bioindicator for water quality assessment on coral reef i.e. specificity, monotonicity, variability, practicality, and relevance. This research showed that although the monitoring of aaptamines production and bioactivity of methanolic extracts is considered practical and relevant, however, further research is needed to evaluate the rest of the above criteria in polluted areas to assure the effect of changes in nutrient loading.

\section{CONCLUSIONS}

No direct correlation between the production of aaptamines and marine pollution was detected in this research, presumably due to the similarity of environmental state along the sampling area. The correlation between inorganic nitrogen contaminant and the bioactivity of crude extract suggests that inorganic nitrogen pollution generates specific stress response in $A$. suberitoides that initiates the production of bioactive compounds in this particular marine sponge.

\section{ACKNOWLEDGMENTS}

Authors would like to acknowledge Gintung Patantis, S. Kel. for his assistance in collecting sponges and Sri Iswani, A. Md. for her help with water analysis.

\section{REFERENCES}

Abdo, D.A., Motti, C.A., Battershill, C.N., and Harvey, E.S. 2007. Temperature and spatiotemporal variability of salicilyhalamide $a$ in the sponge Haliclona $\mathrm{sp}$. Journal of Chemical Ecology. 1635-1645.

Alcolado, P.M. 2007. Reading the code of coral reef sponge community composition and structure for environmental bio-monitoring: some experiences from Cuba. Porifera Research: Biodiversity, Innovation and Sustainability. 3-10.

Aoki, S., Kong, D.X., Suna, H., Sowa, Y., Sakai, T., Setiawan, A., and Kobayashi, M. 2006. Aaptamine, a spongean alkaloid, activates p21 promoter in a p53independent manner. Biochemical and Biophysical Research Communications. 342(1): 101-106.

Becerro, M., Thacker, R.W., Turon, X., Uriz, M.J., and Paul, V.J. 2003. Biogeography of sponge chemical ecology: comparisons of tropical and temperate defenses. Oecologia. 135(1): 91-101.

Bowling, J.J., Pennaka, H.K., Ivey, K., Wahyuono, S., Kelly, M., Schinazi, R.F., Valeriote, F. A., Graves, D.E., and Hamann, M.T. 2008. Antiviral and anticancer optimization studies of the DNA-binding marine natural product aaptamine. Chemical Biology \& Drug Design. 71(3): 205-215.

Camargo, J.A. and Alonso, A. 2006. Ecological and toxicological effects of inorganic nitrogen pollution in aquatic ecosystems. Environment International. 32: 831-849.

Carballo, J.L., Sanchez-Moyano, J.E., and Garcia-Gomez, J.C. 1994. Taxonomic and ecological remarks on boring sponges Clionidae from the straits of Gibraltar (southern Spain): tentative bioindicators? Zoological Journal of the Linnean Society. 112: 407-424.

Cooper, T.F., Gilmour, J.P., and Fabricius, K.E. 2009. Bioindicators of changes in water quality on coral reefs: review and recommendations for monitoring programmes. Coral Reefs. 28: 589-606.

De Voogd, N.J. and Cleary, D.F.R. 2006. An analysis on sponge diversity and distribution at three taxonomic levels in the Thousand Islands/Jakarta bay reef complex, West Java, Indonesia. Marine Ecology. 209: 205-215.

Dewi, A.S. 2010. Stress response on sponges and its potential application as biomonitor of pollutants in coral reef ecosystem. Squalen: Buletin of Marine and Fisheries Post-Harvest and Biotechnology. 5(3): 92100.

Fedoreev, S.A., Prokof'eva, N.G., Denisenko, V.A., and Rebachuk, N.M. 1989. Cytotoxic activity of aaptamines 
from suberitid marine sponges. Pharmaceutical Chemistry Journal. 22(8): 615-618.

Fiore, C.L., Jarett, J.K., Olson, N.D., and Lesser, P.K. 2010. Nitrogen fixation and nitrogen transformations in marine symbioses. Trends in Microbiology. 18 (10): 455-463.

Gul, W., Hammond, N.L., Yousaf, M., Bowling, J.J., Schinazi, R.F., Wirtz, S.S., Andrews, G.D.C., Cuevas, C., and Hamann, M.T. 2006. Modification at the C9 position of the marine natural product isoaaptamine and the impact on HIV-1, mycobacterial, and tumor cell activity. Bioorganic \& Medicinal Chemistry. 14 (24): 8495-8505.

Jumaryatno, P., Stapleton, B.L., Hooper, J.N.A., Brecknell, D.J., Blanchfield, J.T., and Garson, M.J. 2007. A comparison of sesquiterpene scaffolds across different populations of the tropical marine sponge Acanthella cavernosa. Journal of Natural Products. 70: 1725-30.

Kroger, R., Holland, M.M., Moore, M.T., and Cooper, C.M. 2009. Seasonal Patterns of Nitrogen and Phosphorus Losses in Agricultural Drainage Ditches in Northern Mississipi, Agricultural Runoff: Coastal Engineering and Flooding, Editors: Hudspeth, C.A., dan Reeve, T.E. Nova Science Publishers, Inc. pp. 279-289.

Nakamura, H., Kobayashi, J., Ohizumi, Y., and Hirata, Y. 1987. Physiologically active marine natural products from Porifera. 11. Aaptamines-novel benzo [de][1,6]naphtyridines from the Okinawan marine sponge Aaptos aaptos. Journal of the Chemical Society-Perkin Transactions. 1(1): 173-176.

Nuñez, C.V., de Almeida, E.V.R., Granato, A.C., Marques, S.O., Santos, K.O., Pereira, F.R., Macedo, M.L.,
Ferreira, A.G., Hajdu, E., Pinheiro, U.S., Muricy, G., Peixinho, S., Freeman, C.J., Gleason, D.F., and Berlinck, R.G.S. 2008. Chemical variability within the marine sponge Aplysina fulva. Biochemical Systematics and Ecology. 36: 283-296.

Ohizumi, Y., Kajiwara, A., Nakamura, H., and Kobayashi, J. 1984. Alpha-adrenoceptor blockin action of aaptamine, a novel marine natural product, in vascular smooth-muscle. Journal of Pharmacy and Pharmacology. 36(11): 785-786.

Page, M., West, L., Northcote, P., Battershill, C., and Kelly, M. 2005. Spatial and Temporal Variability of Cytotoxic Metabolites in Populations of the New Zealand Sponge Mycale hentscheli. Journal of Chemical Ecology. 31(5): 1161-1174.

Shen, Y.C., Lin, T.T., Sheu, J.H., and Duh, C.Y. 1999. Structures and cytotoxicity relationship of isoaaptamine and aaptamine derivatives. Journal of Natural Products. 62(9): 1264-1267.

Thompson, J.E., Murphyt, P.T., Bergquist, P.R., and Evans, E.A. 1987. Environmentally Induced Variation in Diterpene Composition of the Marine Sponge Rhopaloeides odorabile. Biochemical Systematics and Ecology. 15(5): 595-606.

Wiens, M., Luckas, B., Brümmer, F., Shokry, M., Ammar, A., Steffen, R., Batel, R., Diehl-seifert, B., Schröder, H.C., and Müller, W.E.G. 2003. Okadaic acid: a potential defense molecule for the sponge Suberites domuncula. Marine Biology. 142: 213-223.

Zachary, I. Determination of cell number. In Hughes, D. and Mehmet, $\mathrm{H}$ (eds). 2003. Cell proliferation and apoptosis. BIOS Scientific Publishers Ltd. Oxford. p.17-23. 